\title{
Some Hypotheses About Possible Isolates within the Atlantic Branch of the Niger-Congo Phylum
}

\author{
GUILLAUME SEGERER \\ LLACAN - CNRS - INALCO - Université Sorbonne Paris-Cité
}

\section{Introduction $^{1}$}

The Atlantic branch of the Niger-Congo phylum is known to display much internal diversity as well as a kind of typological coherence, namely the presence of noun classification (as opposed to the neighbouring Mande languages). There has been a continuous (although only among a few scholars) debate over the last $40+$ years about the position of Atlantic within Niger-Congo (NC hereafter) and its internal classification (Dalby 1965, Sapir 1971, Wilson 1989, Childs 2003). Despite the lack of solid evidence of genetic relationship, common scholarship still considers Atlantic to be a valid unit, at least when indicating the genetic affiliation of a particular language. Let aside what Childs (2003:47) terms "scholarly inertia", this can probably be explained by an implicit preference for areal factors over the use of the regular comparative method, because of the lack of reliable data. Today the situation has changed, at least concerning the volume and quality of available data, which allow for a more refined assessment of the relationships between these languages. This paper deals with the status of some potential isolates, i.e. languages that have no more than $20 \%$ of common basic vocabulary with any other so-called Atlantic language (from the figures in Sapir 1971). Four candidates may be proposed: Bijogo, Nalu, Sua and Limba. To these we may Bayot, which we will examine in more detail (data from Diagne 2009).

Bayot, which is not listed in Sapir 1971, is said to be a marginal member of the Joola cluster (Carlton \& Rand 1993). Bayot is a very good case to start with: while at first sight it seems only distantly related to other members of the Joola cluster (12 to $18 \%$ of the core vocabulary), a more detailed investigation shows that regular phonetic correspondances do exist and are relatively numerous,

\footnotetext{
${ }^{1}$ This paper has been written in 2010. While the opinions and hypotheses expressed here still hold, the classification chart in example (1) represents the accepted views of that time. It needs serious revision, which is in progress (Pozdniakov \& Segerer to appear).
} 


\section{Guillaume Segerer}

enough to constitute clear evidence of genetic relatedness. Still, a large part of the Bayot vocabulary is apparently specific to this language. In addition, other features of the language (phonology, TAM markers) are quite different from common Joola: for example, the presence of a complete order of retroflex consonants is unique within Atlantic. Thus, Bayot is arguably both related to and divergent from Joola. The hypothesis is that Bayot was once a different language, and that centuries of continuous contact (today the Bayot people occupy a handful of villages surrounded by speakers of Joola varieties) have resulted in important borrowing in both lexicon and grammar. The Joola influence is such that at present, Bayot may be regarded either as a Joola language with a substrate or as an isolate with a Joola superstrate.

In both cases we would like to know the origin of the "first layer". It seems obvious that it belongs to the Niger-Congo stock, but on the other hand its typical $\mathrm{NC}$ features, e.g. noun classes or verbal extensions are mostly identical to those of common Joola (including lexical items widespread in NC languages). Hence, there is little evidence that proto-Bayot (i.e. Bayot prior to Joola influence) was of the classic NC type.

A quick assessment of the position of other possible Atlantic isolates such as Sua, Nalu, Limba and Bijogo will be made.

\section{The Atlantic Languages}

Spoken on the westernmost coast of Africa, the languages known as Atlantic form a group for which there is no convincing evidence of genetic relationship. Instead, they have been put together on the basis of a few lexical resemblances, and, above all, because they contrast with the neighbouring Mande languages as they display more or less complex noun class systems. It is therefore not surprising that, so far, no serious attempt has been made to elaborate a thorough classification of these languages based on the standard comparative method. Though, some of the proposed subgroups have been given special attention and may be considered as valid genetic units, even if one cannot say to what level these units pertain. Figure (1) on next page presents a simplified overview of the Atlantic languages, based on Sapir 1971 (the bricks left to the labels represent individual languages).

\subsection{Atlantic Subgrouping}

The table in Sapir (1971) gives lexicostatistical counts for 34 Atlantic languages. Most of the figures are below 20\%. This 20\% threshold may be used to identify the most "solid" subgroups, namely : Fula-Sereer-Wolof, Cangin, Tenda-Nyun, Bak, Mel, some of which are shown on table $1.20 \%$ is a very low figure for establishing genetic relationship, and if we now set the threshold at, say, $50 \%$, only those clusters whose internal coherence is obvious at first glance still 


\section{Isolates within the Atlantic branch of the Niger-Congo phylum}

emerge.

It is not possible, within the limits of this paper, to give a full assessment of the problems that one faces comparing Atlantic languages. They display a great variety of phonological and morphological features. For example, some of these languages have a complex system of consonant mutation; some of them have noun class suffixes, others have noun class prefixes and others have both; some have tones and some don't; some have ATR-based vowel harmony and some don't.

(1) Internal structure of the Atlantic branch of Niger-Congo

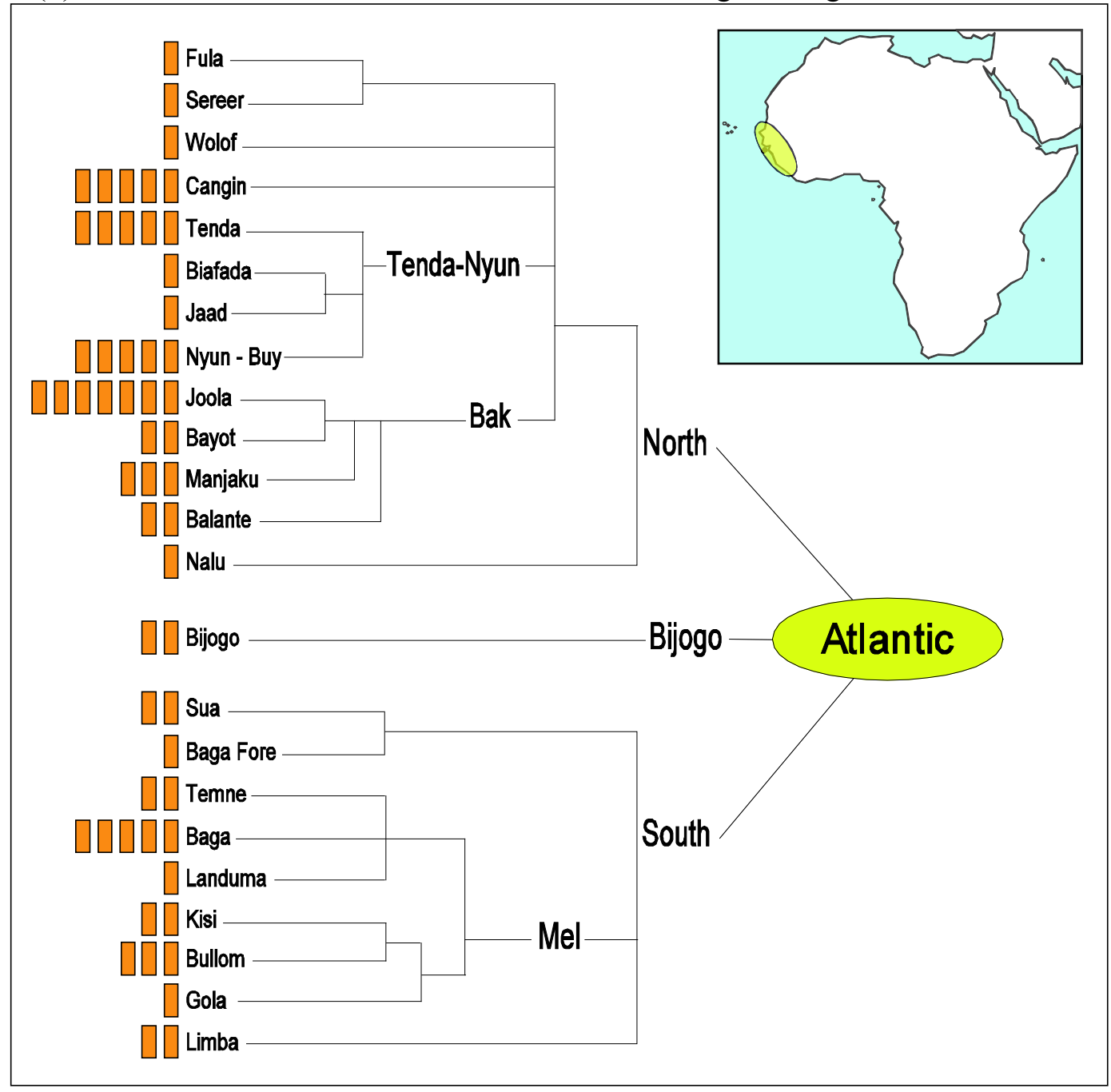

\subsection{Identifying Cognates}

The diversity of these languages makes it difficult to find lexical resemblances, and may explain the very low figures found in lexicostatistical counts. The way these figures were obtained is made explicit by Sapir in a footnote (op. cit. p. 49): 


\section{Guillaume Segerer}

The relevant feature in a count of this sort is the relative and not absolute percentages. As a rule of thumb matches were accepted as putative cognates if each phoneme in a CVC sequence was either identical in the compared forms or varied by no more than a single phonetic feature.

Resemblances of the kind stated by Sapir is considered putative cognacy, which means that they are supposed to reveal common genetic origin. Actually, they are based on mere similarity of segments. There is a paradox in this method: if two languages share only $10 \%$ of basic vocabulary, as do Bijogo and Joola Kasa for instance (Sapir op. cit), their common ancestor, if any, can only be a very distant one. In such a case, one should expect many sound changes having taken place, leading to modern forms showing relatively few resemblances. Consequently, the $10 \%$ of identical (or nearly identical) lexical stems must fall in one of two cases : either they contain segments that have not changed a lot, and these segments, probably scarce, should be present in most of the resembling items (unfortunately Sapir 1971 does not show the items he considers as cognates); or these are borrowed forms, be it from one of the two languages toward the other or from a third language. In this latter case, the common basic vocabulary is not an evidence of common origin anymore. I will illustrate this with examples taken from Bijogo and Joola Kasa, two languages usually considered not to be directly related. Bijogo alone constitutes one of the three branches of Atlantic while Joola Kasa is part of the Bak group of the Northern branch. The two lexical items presented below show how a few sound changes may lead to very different forms. The sound changes in question are based on sound correspondances which, although not found in a large number of items, may still be considered regular and not ad hoc.

\begin{tabular}{|c|c|c|c|c|}
\hline & & $\begin{array}{c}\text { *Bij-Bak } \\
\text { *bu-gof head } \\
\text { *di-ges eye }\end{array}$ & & \\
\hline Bijogo & & & & Joola Kasa \\
\hline$* \mathrm{~g}>\mathrm{n}, * \mathrm{~d}>\mathrm{n}$ & 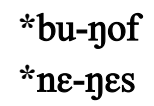 & & $\begin{array}{l}\text { *bu-kof } \\
\text { *di-kis }\end{array}$ & $*_{\mathrm{g}}>\mathrm{k}$ \\
\hline${ }^{*} \mathrm{C}[$ fric, vls $]>\varnothing /$-\# & 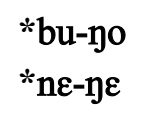 & & $\begin{array}{l}\text { *bu-kow } \\
\text { *di-kil }\end{array}$ & ${ }^{*} \mathrm{C}[$ fric, vls $]>$ glide $/$ \# \\
\hline$*_{\eta}>\varnothing / V-V$ & $\begin{array}{l}{ }^{*} \mathrm{bu}-\mathrm{o} \\
{ }^{*} \mathrm{n} \varepsilon-\varepsilon\end{array}$ & & ji-cil & $* \mathrm{C}>\mathrm{C}[\mathrm{pal}] /-\mathrm{V}[$ front $]$ \\
\hline $\mathrm{V} 1 \mathrm{~V} 2>\mathrm{V} 1$ & $\begin{array}{l}\mathrm{bu} \\
\mathrm{n} \varepsilon\end{array}$ & actual forms & $\begin{array}{l}\text { fu-kow } \\
\text { ji-cil }\end{array}$ & class change (optional) \\
\hline
\end{tabular}




\section{Isolates within the Atlantic branch of the Niger-Congo phylum}

As can be seen on table (2), the actual pair of forms bu / fu-kow 'head' and $n \varepsilon$ / ji-cil 'eye', although most probably coming from a common origin via a few sound changes, don't show the kind of resemblance required to be counted as cognates in Sapir 1971. In other words, Sapir counts as cognates some resemblances that are probably not, and doesn't count true cognates which do not show enough resemblance. It is therefore very difficult to rely on the 1971 table to get a detailed internal classification of the Atlantic languages. Be that as it may, this table proves useful to draw a general picture: if one only looks at figures above $20 \%$, only a few language clusters emerge. These clusters, generally accepted as genetic units, are: Fula-Sereer-Wolof, Cangin, Bak, Tenda-Nyun and Mel. They are shown on figure 3 below, where all figures below $20 \%$ are greyed, respectively from top-left to bottom-right. These clusters are of course quite different as for internal homogeneity: the Cangin languages, with figures ranging from 55 to 79 are much closer to each other than the Mel languages for which the lowest figure is only 20.

\section{(3) D. Sapir's 1971 lexical count for Atlantic}

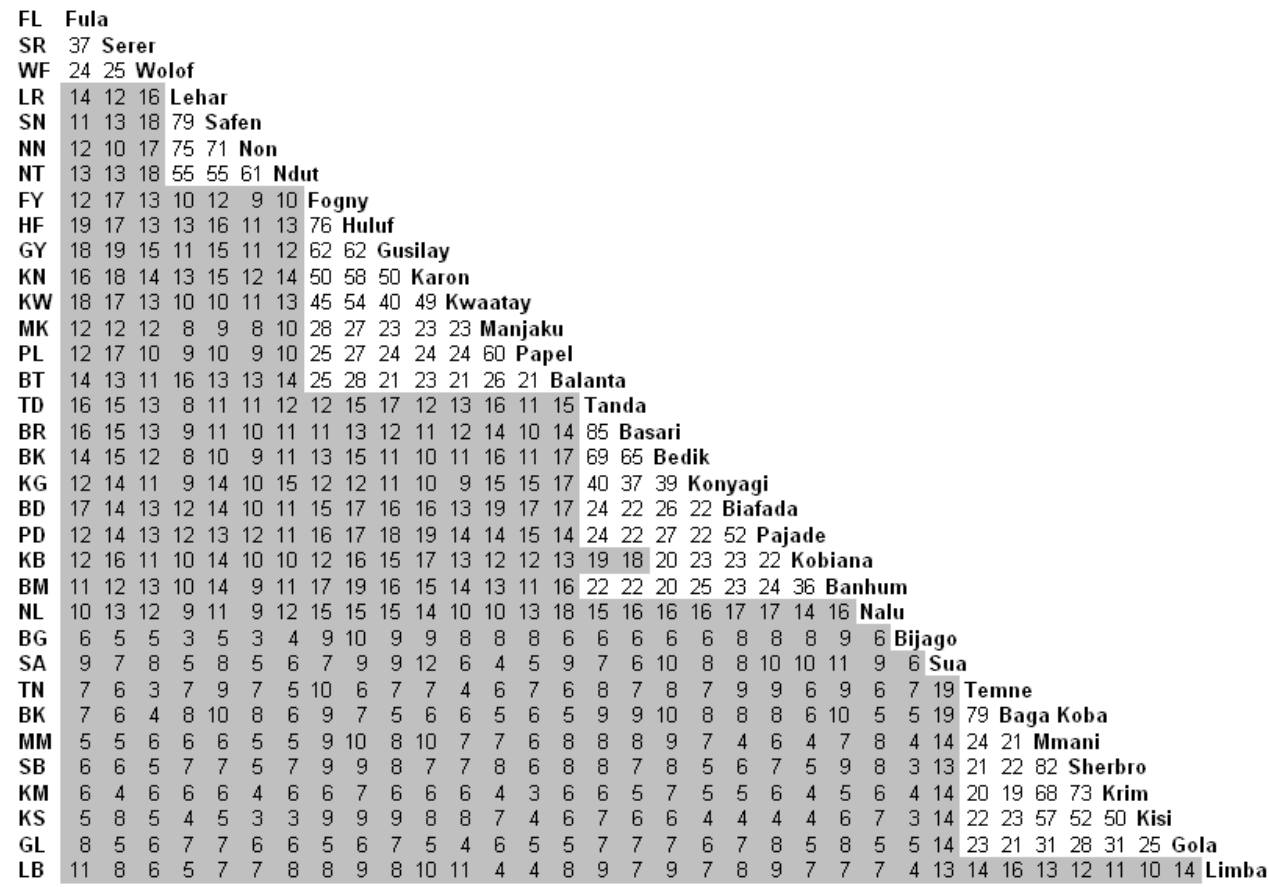

Besides these clusters, a few languages in the above table appear as isolates: their highest score with any other Atlantic language is under 20\%. These are Nalu, Bijogo, Sua and Limba. Before turning to Bayot, we will briefly examine the situation of these four languages. 


\section{Guillaume Segerer}

\section{Status of 'Atlantic Isolates'}

At the time Sapir wrote his paper (1971), only a few Atlantic languages were documented. Apart from well-known languages such as Fula, Wolof and, to a lesser extent, Temne, the only grammatical descriptions of Atlantic languages were his own 'Grammar of Diola Fogny' (Sapir 1965) and Westermann's grammar of Gola (1921). All the remaining languages in the above table were only known by very short sketches and word lists, most of them collected and provided by W.A.A. Wilson in 1958. Wilson's data, including the word lists, have recently been published (Wilson 2007).

Bijogo (Bijago) is an Atlantic branch in itself, for the sake of its very low percentage of lexical resemblances with any other Atlantic language. It is nevertheless a very typical Niger-Congo language with a fully operational nounclass system, suffixed verbal extensions, CVC lexical roots. As examplified above, regular sound correspondances found between Bijogo and Joola indicate that Bijogo should probably be reclassified as a Bak language. A grammar (including a lexicon) is available since 2002 (Segerer 2002).

Nalu, despite a few resemblances with some neighbouring Mel languages, is lexicostatistically closer to the Northern branch of Atlantic. The amount of available descriptive material is nearly the same as it was in 1971: short word lists. From a very superficial personal investigation, I believe there are at least two major dialectal varieties. Nalu is spoken in Both Guinea and Guinea-Bissau but only in a handful of villages as it seems. This language is most probably endangered.

Sua, also an endangered language, is spoken near the city of Mansoa in Guinea-Bissau. That is why it is also known as Mansoanka, a Mandingo name. Like for Nalu, there is no more than a few word lists available, most of them unpublished. Dialectal variation may have been important, especially between a variety influenced by Mandingo and a variety influenced by Balanta. In other words, Sua is undergoing heavy external influence.

Limba is one of the very few Atlantic languages for which there exists a copious dictionary. This dictionary has been compiled by Mary Lane Clarke in 1922, and all subsequent references on the language have taken it as their primary source. It contains more than 4,500 words but unfortunately no grammatical information.

These 3 latter languages (Nalu, Sua, Limba) have in common that they are all understudied, especially in terms of grammatical description

\subsection{Bayot: A Newcomer}

There is another language showing very few lexical resemblances to others, namely Bayot. It is spoken in southern Senegal, in some villages between the city of Ziguinchor and the border with Guinea-Bissau. The Eramme language, spoken 


\section{Isolates within the Atlantic branch of the Niger-Congo phylum}

in a few villages in Northern Guinea-Bissau, is most probably a variety of Bayot. All the Bayot-speaking villages are enclosed in Joola-speaking areas.

The first piece of information about the Bayot language is probably Tastevin's wordlist (1936), which until recently was the longest available (268 items). As this source has not been used by Sapir in his 1971 survey (although the language itself is mentioned), Bayot remained quite unknown for two more decades. In turn, W.A.A. Wilson, in his chapter on Atlantic in J. Bendor-Samuel's The NigerCongo languages (Wilson 1989), merely gives a mention of the language, putting it, like Sapir, in the Joola cluster of the Bak subgroup of the Northern Branch. Two years before however, A. Barry completed a PhD on the classification of the Joola languages (Barry 1987), where he gives word lists for 21 Joola varieties including 3 Bayot ones. Barry concludes, as did Sapir and Wilson, that Bayot is a kind of Joola, although the percentage of resemblances between Bayot and Joola varieties is never above 25\% (Barry 1987:70). He groups the 3 Bayot varieties under the term Southern Joola.

From 1987 to 1989, an extensive survey on the Joola languages was conducted by a team of SIL linguists, and the results were published in 1993 (Carlton \& Rand 1993). 31 villages were investigated, including 2 Bayot villages. Carlton \& Rand's work includes lexicostatistical counts, in which Bayot shows only 12 to $18 \%$ of shared basic vocabulary with Joola languages (a little less than in Barry's count). In the light of these figures, and provided that Bayot is not closer to any other Atlantic language than it is to Joola, Bayot could reasonably be considered an Atlantic isolate, alongside with Nalu, Sua, or Limba.

Thus, all the sources on Bayot are purely lexical. All except one: a $\mathrm{PhD}$ thesis defended in 2009 in Paris (Diagne 2009) presents the first grammatical description of the language, allowing for comparison of various structural elements with the corresponding elements of Joola.

\section{$2.2 \quad$ A Joola Language?}

Despite its lexical distance from the core of Joola languages, Bayot has many features in common with Joola. First of all, its noun class system is very similar to that of Joola. The prefixes are nearly the same or, put in another way, nearly every Joola noun class prefix has an equivalent in Bayot, as shown in table 4:

(4) The main noun class prefixes of (common) Joola and Bayot

$\begin{array}{llllllllllllllll}\text { JoOLA } & \text { a } & \text { ku } & \text { e } & \text { si } & \text { bV } & \text { u } & \text { fu } & \text { ku } & \text { ni } & \text { ka } & \text { mu } & \text { ma } & \text { ji } & \text { ba } & \text { ti } \\ \text { Bayot } & \text { a } & \text { ku } & \text { e } & \text { i } & \text { bV } & \text { o } & \text { f } & & \text { na } & \text { ka } & \text { mu } & \text { ma } & \text { ji } & \text { ba } & \end{array}$

Second, some phonological features are very similar too, as for instance ATRbased vowel harmony with two sets of 5 vowels each, a pattern which, if not rare, is by far not the most common one in West Africa. 


\section{Guillaume Segerer}

Third, it is easy to find regular sound correspondances between Bayot and the core Joola languages, as illustrated in tables 5,6 and 7:

(5) *Joola $t /$ Bayot $r$

\begin{tabular}{|l|l|llll|l|}
\hline & *Joola & Kwaatay & Fogny & Kasa & Banjal & Bayot \\
\hline to fish & *-buut & buutu & buut & but & bbut & bor \\
to die & *-ket & ket & cet & ket & Set & ser \\
middle & *-tut & tut & tut & tut & tut & tur \\
to let & *-kat & & kat & kat & & kar \\
to hit & *-tek & & tek & tek & tex & re? \\
five & *-tok & tok & tok & tok & tox & ro? \\
\hline
\end{tabular}

(6) *Joola k / Bayot Ø

\begin{tabular}{|l|l|llll|l|}
\hline & *Joola & Kwaatay & Fogny & Kasa & Banjal & Bayot \\
\hline animal & *-nukur & nukukur & nukur & nukul & nuxur & no \\
to sit & *-lak & & lak & lak & & la \\
palm-wine & *-nuk & nuk & nuk & nuk & nux & no \\
day & *-nak & nak & nak & nak & nax & na \\
to see & *-juk & juk & juk & juk & jux & zo \\
five & *-tok & tok & tok & tok & tox & ro \\
\hline
\end{tabular}

(7) *Joola -I / Bayot -o

\begin{tabular}{|l|l|llll|l|}
\hline & *Joola & Kwaatay & Fogny & Kasa & Banjal & Bayot \\
\hline to crawl & *-fuul & hun & fúúl & hul & ffúl & fuo \\
breast & $*_{\text {-iil }}$ & in & il & il & il & io \\
eye & *-kil & kin & cíl & kil & Síl & sio \\
lip & *-bil & bin & bil & bil & bil & Bio \\
\hline
\end{tabular}

This latter piece of evidence should definitely put Bayot in the same genetic unit as Joola. The nature of the correspondances shown above (in every series, Bayot clearly departs from Joola varieties) even allows to say that Bayot is likely to have separated first from proto-Joola, thus confirming the hypotheses deduced from lexicostatistics alone.

However, some puzzling features of Bayot, partially hidden by the paucity of available descriptive material before Diagne's work, might shed a different light on its position. 


\section{Isolates within the Atlantic branch of the Niger-Congo phylum}

\subsection{Not a Joola Language?}

The first domain where Bayot 'unusual' features are found is phonology. The consonant inventory of Bayot is significantly different from that of Joola (the various Joola varieties display only a few minor differences with each other). Following Diagne, it includes a complete series of oral retroflex consonants: $/ \mathrm{t}$, $/ \mathrm{d} /, / \mathrm{l}, / \mathrm{r} /$. While the presence of a voiceless retroflex $(/ \mathrm{t} /)$ is not uncommon in the region (see Bijogo, Manjaku), it is unattested in Joola. Moreover, no other Atlantic language shows more than one phonemic retroflex consonant.

The vowel inventory, said above to parallel that of Joola, is actually a little bit different. In addition to the 10 'classic' vowels (grouped in 2 sets following the Advanced Tongue Root feature), Diagne lists 5 nasal vowels, apparently of the -ATR type (but this point is not fully discussed, cf. Diagne 2009:36-38). Not only is this kind of inventory extremely unusual, but the presence of nasal vowels itself is exceptional for Atlantic.

Bayot also differs from Joola when it comes to morphology: while it is true that many noun class prefixes are the same in Joola and Bayot, one must add that Bayot has a few alternate forms that don't exist in Joola. Table 8 below is a modified version of table 4, with Bayot alternate forms:

(8) The noun class prefixes of Joola and Bayot

$\begin{array}{lcccccccccccccc}\text { JOOLA } & \text { a } & \text { ku } & \text { e } & \text { si } & \text { bV } & \text { u } & \text { fu } & \text { ku } & \text { ni } & \text { ka } & \text { mu ma } & \text { ji } & \text { ba ti } \\ \text { Bayot } & \text { a } & \text { ku } & \text { e } & \text { i } & \text { bV } & \text { o } & \text { f } & \text { na } & \text { ka } & \text { mu ma } & \text { ji } & \text { ba }\end{array}$

Bayot also has an extra class $\mathbf{v}-$, which is absent from all Joola varieties. Moreover, Bayot doesn't have any of the 1 to 3 locative classes that are attested throughout the Joola domain. It looks like the Bayot noun class system has undergone strong Joola influence, with only a few remnants from the original system. In fact, in all cases, the alternate forms are neither phonologically nor morphologically conditionned, and these alternate forms aren't attested in any of the Joola varieties. The presence of these alternate forms in Bayot yields a great number of original class pairings, the analysis of which falls beyond the scope of this short paper. Compare for instance the 25 pairings of Bayot (Diagne 2009:96) with the 11 pairings of Joola Banjal (Bassène 2007:32).

As for grammatical paradigms, let's have a look at the sytem of person marking. Table 9 presents an excerpt of the systems of person marking in Bayot and in 4 Joola varieties. All Joola varieties show three different, non-cognate forms for the $1^{\text {st }}$ person singular. Bayot has only two near-identical variants, corresponding to the independant form found in Joola. Elsewhere in the system, only $2^{\text {nd }}$ person singular seems to connect Bayot and Joola. All other forms are clearly not cognates. It is therefore very likely that the Bayot system of person 


\section{Guillaume Segerer}

marking is being partially remodeled after the Joola one.

(9) Joola and Bayot personal pronouns

\begin{tabular}{|c|c|c|c|c|c|c|c|}
\hline & & *Joola & Kwaatay & Fogny & Kasa & Banjal & Bayot \\
\hline \multirow[t]{3}{*}{$1 \mathrm{sg}$} & subj & $*_{i}$ & $\mathrm{i}$ & $\mathbf{i}$ & i & i & je \\
\hline & obj & *om & $\mathrm{am}$ & om & om & om & nje \\
\hline & indep & $*_{\text {inje }}$ & inje & inje & inje & inje & nje \\
\hline $2 \mathrm{sg}$ & indep & *aw & awe & aw & $a u$ & $\mathrm{au}$ & $a b$ \\
\hline 1dual & $"$ & ??? & wane & -- & ola & -- & ya \\
\hline $1 \mathrm{pl}$ inc & $"$ & *olal? & úne & olal & olaal & olal & $\mathrm{i}$ \\
\hline $1 \mathrm{pl} \mathrm{exc}$ & " & *uli & uni & uli & óli & óli & wa \\
\hline $2 \mathrm{pl}$ & $"$ & $*_{\mathrm{ji}}$ & ari & ji & $\mathrm{ji}$ & $\mathrm{ji}$ & ka \\
\hline
\end{tabular}

One can also compare the verb extensions of Joola and Bayot. Verb extensions are one of the diagnostic features of Niger-Congo, and are reputed to be especially widespread in a few branches of this phylum, including Atlantic (Williamson \& Blench 2000). Whereas 'regular' Joola languages display from 8 to 11 distinct verb extensions, Bayot has only 3, all of which similar to the corresponding Joola forms. It seems very unlikely that Bayot, surrounded and heavily influenced by Joola, would have innovated by dropping all but three verb extensions. On the contrary, one might think that Bayot had no verb extensions at all and is progressively borrowing them from Joola.

Finally, let's have a closer look at the lexicon. For each sound correspondance mentionned above where Bayot displays an innovative segment $\left({ }^{*} \mathrm{t}>\mathrm{r},{ }^{*} \mathrm{k}>\emptyset,{ }^{*}-1>-0\right)$, it is possible to find series in which Bayot shows exactly the same segment as Joola:

(10) Sound identities between Joola and Bayot

\begin{tabular}{|l|l|llll|l|}
\hline & *Joola & Kwaatay & Fogny & Kasa & Banjal & Bayot \\
\hline to be light & *-wiil & wiin & & wiil & vvil & vul \\
to catch & *jok $_{\text {jok }}$ & jok & & jok & jox & zok 'choose' \\
heel & *tonj & & tonj & tonj & toj & tor \\
to stick & *kot $^{\text {kon }}$ & kot & kot & kot & xot & kot \\
\hline
\end{tabular}

So far, there is no way to predict what will be the Bayot reflex of ${ }^{*}$ Joola $* \mathrm{k}$, $* 1$, or $*$ t. There seems to be at least two layers of lexical stems, one of which closer to Joola than the other. This can be explained by positing that the difference between these layers corresponds to borrowed $v s$ inherited lexicon respectively. It could as well be a difference between old and recent borrowings, 


\section{Isolates within the Atlantic branch of the Niger-Congo phylum}

the old ones having undergone sound changes that were no more active when the new borrowings entered the language. Anyway, it seems clear that at least a part of the present Bayot lexicon has been borrowed from Joola, even if Bayot is to be considered Joola itself.

\subsection{Discussion}

We have seen that while there are good arguments (including regular sound correspondances) to include Bayot in the Joola cluster, some features suggest that this affiliation is probably not straightforward. From a purely synchronic point of view, Bayot is a Joola language in the sense that it is closer to Joola than to any other language. The question is: how comes that it is so divergent, when other Joola languages form a relatively homogenous cluster? If one assumes that Bayot is genetically close to Joola, there must have been a long period of isolation during which Bayot innovated in a number of ways (possibly through contact with another language, but this can't be demonstrated yet), then a long period of contact during which they borrowed many features from Joola, including some they had previously lost. Another possible story would be that Bayot speakers and Joola speakers once spoke very different languages, and Bayot progressively came to assimilate Joola linguistic features. The unique features of the Bayot language might be seen as remnants of proto-Bayot, as for instance the alternate noun-class markers or the unique personal pronouns (see above). Unfortunately, none of these scenarios can be given any historical support.

The adoption of this latter scenario has further consequences. If proto-Bayot is not Joola, then is it Bak (the genetic unit above Joola, that groups together Joola, Balanta and Manjaku, see table 1 above)? Does it belong to Northern Atlantic? To Atlantic? One can only say that Bayot is a Bak language insofar that it is a Joola language. In fact, no particular feature could be found, which would relate Bayot to Balanta or Manjaku but not to Joola. Regarding Northern Atlantic, and even Atlantic, no linguistic innovation has been put forward so far to characterize these groupings, as it has been stated at the beginning of this paper. That means that Bayot is Atlantic because it has noun classes and it is spoken on the coastal strip between Senegal and Sierra Leone

There is little doubt that proto-Bayot was a Niger-Congo language. Or is there? It certainly had noun classes even if one assumes heavy Joola influence, as shown by the actual alternate forms. But the few verbal extensions are all clearly from Joola origin. And from the very little stock of lexical roots that can be (cautiously) used as a diagnostic tool for Niger-Congo membership, those found in Bayot are all clearly borrowed from Joola. In other words, let aside noun class remnants, none of the linguistic features that can be traced to proto-Bayot can convincingly be said to originate from any well-established NC subgroup. 


\section{Guillaume Segerer}

\section{Conclusion}

The Atlantic branch of the Niger-Congo phylum raises interesting challenges to language classification. While it displays a relative typological coherence (noun classes, rich morphology, verb extensions), lexicostatistics is of little use to reveal its internal structure. A few subgroups emerge, each of which might almost be given the status of an independant Niger-Congo branch: Wilson (1989:92) noted that Papel, a Bak language, scored better (15\%) with Common Bantu than with Bijogo, yet also an Atlantic language. Thus, some of the languages that appear as 'Atlantic isolates' might as well be considered Niger-Congo isolates. On the other hand, we have shown that Bijogo, officially an Atlantic singleton, may be related to the Bak languages, although superficial lexical resemblances are very scarce.

The case of Bayot, a language long ignored by scholars, is different. It seems close to the Joola cluster, but in a way that suggests borrowing through contact instead of common genetic origin. In a synchronic description, Bayot can be called an atypic Joola language, but the hypothesis that proto-Bayot was an unrelated language cannot be ruled out. Furthermore, what can be traced to protoBayot shows no resemblance to any of the neighbouring languages, so that protoBayot should have been an isolate, or the only remaining member of a language group. So far, all the resemblances that have been found between Bayot and other languages involve a language of the Joola cluster. Further work will carefully examine the possible connections between Bayot and non-Joola languages of the same area such as Nyun, Tenda or Jaad.

\section{$4 \quad$ References}

Barry, Abdoulaye. 1987. The Joola languages: subgrouping and reconstruction. Ph.D. thesis, School of Oriental and African Studies, University of London, London.

Bassène, Alain-Christian. 2007. Morphosyntaxe du jóola banjal; Langue atlantique du Sénégal. Köln: Rüdiger Köppe.

Carlton, Elizabeth M., and Sharon R. Rand. 1993. Enquête sociolinguistique sur les langues Diolas de basse Casamance. Dakar: Société Internationale de Linguistique.

Childs, George Tucker. 2003. An introduction to African linguistics. Amsterdam \& Philadelphia: John Benjamins Publishing Co.

Clarke, Mary Lane. 1922. A Limba-English dictionary, or: Tampen ta ka talun ta ka hulimba in huinkilisi ha. New York: Houghton. 


\section{Isolates within the Atlantic branch of the Niger-Congo phylum}

Dalby, David. 1965. The Mel languages: a reclassification of southern 'West Atlantic'. African language studies 6:1-17.

Diagne, Mbacké. 2009. Le Bayot: Langue Atlantique Nord, groupe bak, sous groupe jóola. Ph.D. thesis, Institut National des Langues et Civilisations Orientales, Paris.

Doneux, Jean Léonce. 1975. Hypothèses pour la comparative des langues atlantiques. Africana linguistica VI:41-129.

Sapir, J. David. 1971. West Atlantic: an inventory of the languages, their noun class systems and consonant alternation. In T. A. Sebeok, ed, Current Trends in Linguistics, 7: Linguistics in Sub-Saharan Africa, 45-112, The Hague \& Paris: Mouton \& Co.

Sapir, J. David. 1965. A grammar of Diola-Fogny, a language spoken in the Basse-Casamance region of Senegal. Cambridge: Cambridge University Press in association with the West African Linguistic Society.

Segerer, Guillaume. 2002. La langue bijogo de Bubaque (Guinée Bissau). Louvain, Paris: Editions Peeters, coll. Afrique et Langage 3.

Tastevin, R. P. Constant F. 1936. Vocabulaires inédits de 7 dialectes sénégalais dont 6 de Casamance. Journal de la Société des Africanistes 6(1):1-33.

Westermann, Diedrich. 1921. Die Gola-Sprache in Liberia: Grammatik, Texte und Wörterbuch. Hamburg: Friederichsen, De Gruyter \& Co.

Williamson, Kay and Roger Blench. 2000. Niger-Congo. In Bernd Heine and Derek Nurse, African languages: an introduction, 11-42, Cambridge: University Press.

Wilson, William André Auquier. 1989. Atlantic. In J. T. Bendor-Samuel, ed, The Niger-Congo languages: a classification and description of Africa's largest language family, 81-104, Lanham MD, New York, and London: University Press of America.

Wilson, William André Auquier. 2007. Guinea Languages of the Atlantic Group. Frankfurt: Peter Lang. 


\section{Guillaume Segerer}

Guillaume Segerer

LLACAN - CNRS - INALCO - Université Sorbonne Paris-Cité Paris, France

segerer@vjf.cnrs.fr 